\title{
Upaya Pencegahan Infiltrasi Pada Terapi Intravena Perifer Di Rumah Sakit Awal Bros Batam
}

\author{
Indah Purnama Sari ${ }^{a, b}$, Hema Malini ${ }^{\mathrm{b}}$, Yulia Yasman ${ }^{\mathrm{c}}$ \\ ${ }^{a}$ Mahasiswa Pasca Sarjana, Fakultas Keperawatan, Universitas Andalas, Padang, 25163, \\ Indonesia \\ ${ }^{a}$ Rumah Sakit Awal Bros, Jl. Gajah Mada Kav. 1 Batam, 29444, Indonesia \\ ${ }^{b}$ Fakultas Keperawatan, Universitas Andalas, Padang, 25163, Indonesia \\ c. Rumah Sakit Raja Musa Tanjung Uban,29152, Indonesia \\ e-mail korespondensi: indahpsari560@gmail.com
}

\begin{abstract}
Efforts to prevent infection, such as infiltration, is a critical aspect of the factors that affect the safety of patients. One form of safety for patients is the prevention of infiltration. An initial assessment tool was introduced to the nurses inward in order to ensure they performed the precaution behavior. The purpose of this study is knowing intravenous infiltration prevention efforts that have been done by nurses. The research method is descriptiveobservational, where research using total sampling inpatient nurses to observe the actions of nurses during infusion. There was 82 nurses the population and sampled by the researchers. The observation was conducted in the first week of patients' admission when many activities of intravenous therapy provided by nurses. The study found that nearly all the nurses were able to perform infiltration prevention activities during the infusion. It indicates that the nurse had been able to make active efforts in the prevention of infiltrates. These active efforts will continue to do so suggested the incidence of infiltration or due to the continued infusion of infection can be prevented.
\end{abstract}

Keywords: nurse's role, infiltration, prevention, intravenous therapy, monitoring

\begin{abstract}
Abstrak
Upaya pencegahan infeksi seperti infiltrasi merupakan aspek yang penting terhadap faktor faktor yang mempengaruhi angka keselamatan pasien. Salah satu bentuk keselamatan pada pasien adalah pencegahan terhadap infiltrasi. untuk itu perlu dilakukan upaya dalam dalam mencegah terjadinya infiltrasi, dimana dengan mengenalkan pada tenaga kesehatan terkait instrument penilaian pencegahan infiltrasi. Tujuan penelitian ini adalah mengetahui upaya pencegahan infiltrasi intravena yang sudah dilakukan oleh perawat. Metode penelitian adalah deskritif-observasional, dimana penelitian menggunakan total sampling perawat rawat inap dengan melakukan observasi terhadap tindakan perawat selama pemasangan infus. Ada 82 orang perawat yang menjadi populasi dan dijadikan sampel oleh peneliti. Observasi dilakukan selama 1 minggu di ruang rawat terhadap aktifitas pemasangan infus. Penelitian menemukan bahwa hampir semua perawat mampu melakukan kegiatan pencegahan infiltrasi selama pemasangan infus. Ini menunjukkan bahwa perawat telah mampu melakukan upaya aktif dalam pencegahan infiltrate. Upaya aktif ini disarankan akan terus dilakukan sehingga angka kejadian terhadap infiltrasi ataupun akibat lanjut dari infeksi pemasangan infus bisa dicegah.
\end{abstract}

Keywords: Infiltrasi, monitoring, prevention, terapi intravena

\section{PENDAHULUAN}

Pelayanan Rumah Sakit di era sekarang menjadikan keselamatan pasien menjadi hal yang utama dalam pelayanan kesehatan. Prioritas utama dalam Patient centre care selalu menjadi hal yang diwajibkan dalam semua program rumah sakit antara lain adalah dengan pencegahan terjadinya phlebitis dan infiltrasi pada pasien (Komisi Akreditasi Rumah Sakit, 2018)

Infiltrasi pada pemasangan terapi intravena sering terjadi. Menurut Driscoll (2015) 
angka kejadian infiltrasi di USA sebesar 23-28 \% pada pasien infant. Prevalensi kejadian yang sama didapatkan pada penelitian dengan angka kejadian 23-78 \% di Alabama, Los Angeles (Huey, 2016). Sementara di Rumah sakit Awal Bros Batam. Pada tahun 2017 berdasarkan data dari komite patient safety Rumah Sakit Awal Bros Batam kejadian infiltrasi terdapat 4 kejadian infiltrasi pada 3 pasien dewasa dan 1 pasien anak. Tahun 2018 periode Januari - Maret 2018 ada 3 kejadian infiltrasi yang mengakibatkan terjadinya luka bakar pada pasien. Kejadian infiltrasi didefinisikan sebagai adanya dari cairan atau pengobatan non vesikan mengelilingi jaringan sekitarnya yang menyebabkan potensi cedera pada pasien (Odom, 2018). Sedangkan Prakoso (2016) menyatakan hal yang sama dengan Odom yaitu infiltrasi adalah terjadinya kebocoran cairan non vesikan pada pembuluh darah. Mattox, (2017) menjelaskan infiltrasi adalah masuknya pemberian cairan non vesican ke jaringan sub cutaneous dan keluar dari pembuluh darah pasien.

Kejadian infiltrasi sering dilihat sebagai kejadian yang tidak berbahaya. Infiltrasi ditandai dengan kulit memucat, tembus cahaya, kebocoran, perubahan warna, memar dan bengkak, edema, pitting edema dalam, gangguan sirkulasi, nyeri sedang sampai berat, infiltrasi dengan adanya keluar product darah, iritan atau non vesicant (Bartholomay et al., 2015). Infiltrasi tidak mengakibatkan nekrosis jaringan seperti yang terjadi pada pemberian terapi yang bersifat cairan vesikan. Namun volume besar infiltrasi dapat menyebabkan kompresi pada system saraf dan sindrom kompartemen ekstremitas akut, yang akan mengakibatkan kecacatan jangka panjang. Penelitian Miller (2016) di Amerika Serikat seorang bayi mengalami infiltrasi grade 4 yang mengakibatkan cedera parah pada ekstermitas bayi, extremitas menjadi pucat dan tidak adanya capillary refill time sehingga terjadi kematian jaringan pada area tersebut. Penjelasan Miller tersebut diperkuat dengan penelitian yang dilakukan Driscoll (2015) bahwa infiltrasi grade 4 mengakibatkan kerusakan kulit dan nekrosis. Extremitas yang mengalami infiltrasi akan menjadi terbakar, nyeri, memutih dan parastasia. Berbagai dampak yang ditimbulkan infiltrasi tersebut dapat menimbulkan cedera pada pasien dan akan menambah masa rawatan pasien di rumah sakit (Mattox, 2017).

Sementara di Indonesia, belum ada angka yang pasti berapa kejadian infiltrasi, tetapi penelitian yang banyak ditemukan adalah angka plebitis yang yang merupakan hal yang berbeda dengan infiltrasi. Banyak faktor dapat mengakibatkan terjadinya infiltrasi antara lain adalah lokasi pemilihan vena yang tidak tepat dengan ukuran intravena yang dipasang, fiksasi yang tidak menggunakan transparan dressing yang membuat monitoring tidak dilakukan dengan baik, dan proses kebersihan tangan yang tidak dilakukan. Ada perbedaan yang mendasar antara infiltrasi dan phlebitis dimana kejadian infiltrasi tidak ditandai dengan adanya gambaran peradangan pada pembuluh darah pasien sedangkan pada kejadian phlebitis, akan nampak dengan jelas gambaran peradangan pembuluh darah pasien. Data infiltrasi di Indonesia belum tergambar dibeberapa literature yang lebih banyak tergambar adalah kejadian phlebitis yang terjadi pada beberapa rumah sakit. Penelitian Akbar (2018) di Rumah Sakit Cipto Mangunkusumo didapatkan jumlah kejadian phlebitis sebanyak $17,11 \%$ dari 109 pasien yang mendapatkan terapi cairan intravena dengan rata rata kejadian setelah dua hari pemasangan. Hartati (2016) di Rumah Sakit Umum Daerah dr. Soediran Mangun Soemarso Wonogiri memaparkan angka kejadian plebitis yang lebih tinggi yaitu $18.6 \%$. Penelitian Riris \& Kuntarti, (2014) mendapatkan angka kejadian flebitis yang lebih tinggi di tiga Rumah Sakit di Jakarta yaitu sebesar 33.8\%.

Rumah Sakit Awal Bros telah berdiri sejak tahun 2003, sampai dengan tahun 2016 
belum memiliki data kejadian infiltrasi. Rumah Sakit Awal Bros Batam sudah memiliki SOP pemasangan infus yang sudah dilakukan revisi pada tahun 2016 dengan menambahkan penggunaan transparan dressing pada area tusukan infus. Pada tahun 2017 berdasarkan data dari komite patient safety Rumah Sakit Awal Bros Batam kejadian infiltrasi terdapat 4 kejadian infiltrasi pada 3 pasien dewasa dan 1 pasien anak. Tahun 2018 periode Januari - Maret 2018 ada 3 kejadian infiltrasi yang mengakibatkan terjadinya luka bakar pada pasien. Pada bulan April 2018 kejadian infiltrasi 31 dari 1226 hari pasien terpasang infus, bulan Mei kejadian infiltrasi 13 dari 1608 hari pasien terpasang infus dan pada bulan Juni sebanyak 20 infiltrasi dari 1183 hari pasien yang terpasang infus.

Deteksi dini terhadap infiltrasi merupakan keharusan dilakukan di rumah sakit. Ada banyak tindakan yang dapat dilakukan agar infiltrasi tidak terjadi antara lain pengetahuan staf tentang bagaimana pencegahan infiltrasi, pengetahuan tentang prosedur yang benar dalam melakukan kebersihan tangan dan lainnya. Riris \& Kuntarti (2017) dalam penelitiannya mengatakan perlunya pemahaman perawat tentang monitoring yang tepat lokasi intravena. Pencegahan lebih lengkap dijelaskan dalam penelitian Prakoso, (2016) dengan 12 benar dalam pencegahan infiltrasi pada pasien. Sementara Barbara (2012) melakukan berbagai perubahan kebijakan dalam pencegahan infiltrasi peripheral antara lain dengan metode TLC (Touch, Look and Compare) secara rutin pada pemasangan intravena periper. Pencegahan infiltrasi akan melibatkan perawat sebagai pemberi pelayanan keperawatan sehingga diperlukan pengetahuan dan pemahaman yang bagus dari tenaga keperawatan untuk bisa melaksanakan program pencegahan infiltrasi pada pasien.

Prakoso (2016) menjelaskan bahwa seorang perawat memiliki tanggung jawab untuk memastikan pemberian intravena tidak menimbulkan kejadian infiltrasi dan phlebitis. Perawat memiliki peran yang penting dalam melakukan monitoring dan mempertahankan terapi intravena terapi tersebut kepada pasien. Monitoring tanda dan gejala komplikasi serta intervensi terhadap pencegahan merupakan tanggung jawab dari pemberi pelayanan (Driscoll, 2015).

Pencegahan infiltrasi yang dijelaskan oleh Prakoso (2016) antara lain adalah benar dalam penusukan, benar penggunaan kateter, benar dalam terapi intravena, benar dalam melakukan antiseptic, benar teknik flushing, benar edukasi, benar fiksasi dan benar osmolaritas cairan yang direkomendasikan. Pencegahan infiltrasi juga dapat dilakukan oleh perawat melalui peningkatan kompetensi, komunikasi dan kerja tim serta kegiatan audit terhadap proses pemasangan intravena terapi diruangan (Miller, 2016). Untuk melakukan monitoring diatas perlu adanya instrumen yang digunakan untuk sebagai acuan dalam melakukan pencegahan kejadian infiltrasi pada pasien

Peneliti melakukan penelitian dengan mengevaluasi tindakan pencegahan infiltrate yang sudah dilakukan oleh perawat. observasi pelaksanaan tindakan pencegahan infiltrasi pada pasien yang dilakukan oleh perawat rawat inap di rumah sakit Awal Bros Batam. Observasi tersebut meliputi: pengunaan Intravena catheter dalam keadaan steril, pencatatan nama dan lokasi vena pada pemasangan intravena cateter, penggunaan transparan dressing pada area tusukan, dokumentasi setelah pemasangan dilakukan dan melakukan monitoring pada area tusukan.

\section{METODE}

Penelitian ini adalah penelitian deskritif kuantitatif dengan melakukan melakukan pengukuran terhadap kegiatan perawat melakukan pemasangan infus dengan berdasarkan pada kegiatan yang perlu diperhatikan dalam pencegahan infiltrasi. Sampel diambil dari total 
sampling perawat rawat inap yang melakukan pemasangan infus pada pasien yang berjumlah 82 perawat di Rumah sakit Awal Bros Batam. Observasi dilakukan pada semua unit rawat inap dengan menggunakan instrument penelitian. Instrumen penelitian adalah lembar ceklist observasi yang berasal dari 12 Benar dalam pemasangan infus yang di paparkan oleh Prakoso (2016) dalam pelatihan Advance Vaskuler Akses yang kemudian dikembangkan dengan kajian literature dan masukan dari 4 orang panel expert dalam proses metode delphie. Instrumen juga mempertimbangkan adanya SOP yang sudah dilakukan untuk pencegahan terhadap infiltrasi. Instrumen sudah dilakukan uji Validitas r-tabel > r Hitung yaitu sebesar 0.2540 dan Cronbach's Alpha sebesar 0.533. Terhadap tindakan perawat terdiri dari 5 penilaian yaitu : pengunaan Intravena Chateter dalam keadaan steril, pencatatan nama dan lokasi vena pada pemasangan intravena cateter, penggunaan transparan dressing pada area tusukan, dokumentasi setelah pemasangan dilakukan dan melakukan monitoring pada area tusukan. Pencegahan infiltrasi sebagian langkah adalah sama dengan pencegahan phlebitis tetapi phlebitis bisa dicegah lebih cepat jika perawat melakukan pencegahan infiltrasi dengan instrument yang telah dibuat. Pada prinsipnya item pada instrument pencegahan infiltrasi akan mengadopt sebagian tindakan yang dilakukan dalam SOP pemasangan infus tetapi instrument ini dilakukan untuk mempermudah mengingat apa saja yang perlu dilakukan dalam mencegah infiltrasi pada pasien.

\section{HASIL}

Hasil penelitian menunjukkan karakteristik perawat dan tindakan pencegahan infiltrasi yang dilakukan perawat. Karakteristik perawat meliputi umur, jenis kelamin yang dapat dilihat pada tabel 5.1.
Keseluruhan dapat dilihat pada tabel 5.1

Tabel 5.1

Distribusi Frekuensi Perawat

Rawat Inap Berdasarkan karakteristik di Rumah Sakit Awal Bros Batam Tahun $2019(\mathbf{n}=82)$

\begin{tabular}{|c|c|c|c|c|}
\hline No & karakteristik & Kategori & $\mathbf{f}$ & $\%$ \\
\hline \multirow[t]{2}{*}{1} & Umur & $\leq 30$ tahun & 63 & 76.8 \\
\hline & & $\geq 30$ tahun & 19 & 28.4 \\
\hline \multirow[t]{2}{*}{2} & Pendidikan & DIII & 44 & 53.9 \\
\hline & & Ners & 38 & 46.3 \\
\hline \multirow[t]{4}{*}{3} & $\begin{array}{l}\text { Pengalaman } \\
\text { kerja }\end{array}$ & $\leq 2$ Tahun & 32 & 39.3 \\
\hline & & 2 - 6 Tahun & 24 & 29.2 \\
\hline & & $\begin{array}{l}\geq 6-9 \\
\text { Tahun }\end{array}$ & 12 & 14.6 \\
\hline & & $\geq 9$ Tahun & 10 & 12.1 \\
\hline \multirow[t]{2}{*}{4} & Jenis Kelamin & Laki Laki & 10 & 12.1 \\
\hline & & PR & 72 & 87.8 \\
\hline
\end{tabular}

Tabel data demografi memperlihatkan dari 82 perawat pelaksana sebagian besar berusia $\leq 30$ tahun adalah $76.3 \%$. Hartati, (2016) dengan kelompok usia terbanyak $<30$ tahun dengan kinerja baik. Karakteristik pendidikan terlihat dengan $53.9 \%$ memiliki pendidikan DIII, pembagian distribusi diambil berdasarkan Kemenkes RI (2017) yang membagi menjadi beberapa kategori Perawat Klinik berdasarkan Masa kerja. Distribusi pengalaman kerja yang lebih banyak adalah pengalaman $\leq 2$ tahun sebanyak $39.3 \%$ merupakan perawat yang disebut Perawat Klinik I dan jika dilhat dari jenis kelamin terbanyak adalah $87.8 \%$ berjenis kelamin perempuan.

Hasil Observasi didapatkan bahwa $96 \%$ perawat melakukan pencegahan infiltrasi kepada pasien. Gambaran observasi tersebut tergambar dibawah ini : 




\section{PEMBAHASAN}

Berdasarkan hasil observasi terhadap 82 tindakan pemasangan infus, $96 \%$ pencegahan infiltrasi sudah dilakukan dengan benar oleh perawat. Pelaksanaan pencegahan infiltrasi berlaku sesuai standard baik oleh perawat dengan masa kerja yang lebih lama maupun oleh perawat yang memiliki masa kerja lebih sedikit. Pada observasi penggunaan intravena cateter steril, semua pasien yang dilakukan pemasangan infus mengunakan intravena yang masih dikemas rapi dari pabrik. Perawat membuka kemasan sesaat akan melakukan penusukan. Jika gagal pada tusukan pertama, perawat akan mengambil kemasan yang baru untuk ditusukkan kepasien. Setelah intravena cateter berhasil dipasang, perawat akan memberikan tranparan dressing untuk menutup area tusukan, hasil observasi menunjukkan 82 pasien sudah diberikan transparan dressing.

Selanjutnya observasi dilakukan pada pemberian transparan dressing, observasi dilanjutkan dengan melihat apakah area tususkan diberikan label yang jelas, dan dari hasil pengamatan didapatkan , masih ada 3\% tindakan perawat yang tidak sesuai standar dimana pada area tusukan tidak diberikan label.
Observasi dilakukan kembali dengan melihat perawat melakukan dokumentasi dari 82 pengamatan, $96 \%$ telah dilakukan pencatatan kapan infus dipasang, oleh perawat siapa, lokasi infus tersebut dipasang dan terdapat $4 \%$ perawat yang tidak melakukan dokumentasi setelah melakukan pemasangan infus. Sementara itu, dari 82 pasien tersebut, $100 \%$ perawat sudah memberikan fiksasi transparan pada area tusukan dan Intravena kateter yang digunakan adalah intravena kateter steril.

Meskipun masih belum sempurna keseluruhan tindakan, namun ini menunjukkan bahwa perawat di Awal Bros Batam telah mempunyai internalisasi terhadap nilai dan standar dari pencegahan infilitrasi. Penelitian Irnawati (2014) menemukan penyebab dari tidak diikutinya SPO diruangan dalam pemasangan infus oleh perawat mengakibatkan angka kejadian komplikasi dari pemasangan infus meningkat dialami oleh pasien.

Tindakan pencegahan infiltrasi yang dilakukan oleh perawat sangat dibutuhkan untuk mencegah pasien mengalami infiltrasi. Secara otomatis perawat ikut memberikan keamanan dengan pemberian pelayanan keperawatan yang berkualitas yang mendukung terciptanya keselamatan pasien dalam pelayanan kesehatan

\section{KESIMPULAN}

Peneliti dapat menyimpulkan bahwa tindakan pencegahan infiltrasi sudah berjalan dengan baik di Rumah Sakit Awal Bros Batam. Penyebaran DIII dan Skep NS yang hampir seimbang akan memberikan dampak positif dalam pelaksanaan instrument pencegahan infiltrasi. Ditambah lagi dengan usia terbanyak < 30 tahun akan menunjukkan kinerja yang baik. Pencegahan infiltrasi pada pemasangan intravena perifer sangat diperlukan mengingat setiap pasien dirawat inap akan dilakukan pemasangan infus dan perawat merupakan tenaga kesehatan yang 24 jam berada disamping pasien. Petugas kesehatan khususnya perawat bisa 
melakukan pencegahan infiltrasi dengan melakukan berbagai tindakan pencegahan kepada pasien. Melalui penelitian ini, diharapkan instrumen ini dapat digunakan oleh perawat dan peneliti lainnya dalam melakukan pencegahan kejadian infiltrasi dan mencegah kejadian cedera pada pasien akibat pemasangan infus.

Observasi yang dilakukan bisa dilanjutkan untuk melihat apakah perawat sudah melakukan berbagai tindakan pencegahan infiltrasi pada pasien. Hal ini tentunya akan dapat mengurangi cedera pada pasien akibat pemasangan intravena perifer. Tindakan selanjutnya yang bisa dilakukan adalah membuat instrument yang bisa digunakan dalam pencegahan infiltrasi pada pasien dan digunakan oleh perawat setiap melakukan pemasangan infus. Secara umum perawat di rumah sakit awal bros telah mempunyai perilaku yang baik terkait dengan tindakan pencegahan

\section{UCAPAN TERIMA KASIH}

Terima Kasih dr. Widya Putri yang sudah memberikan dukungan untuk terlaksananya penelitian ini.

\section{DAFTAR PUSTAKA}

Akbar. (2018). Pengaruh karakteristik pasien yang terpasang kateter intravena terhadap kejadian phlebitis (flebitis).

Bartholomay, M. (Massachusetts G. H., Dreher, D., Evans, T., Finn, S., Guthrie, D., Lyons, H., ... Tyksienski, C. (n.d.). Nursing Management of Venous Access Devices: Peripherally Inserted Central Catheter (PICC).

Retrieved from http://www.mghpcs.org/EED_Portal/ Documents/Central_Lines/CL_Modul e8.pdf

Driscoll. (2015). Improving Detection of IV infiltratrates in Neonates.
Hartati. (2016). Hubungan tingkat pengetahuan perawat tentang plebitis dengan kepatuhan melaksanakan SOP pemasangan infus pada BBLR.

Huey, T. W. M. and T. K. (2016). DecreasingIV Infiltrates in The Pediatric Patient - System Based Improvement Project.

Irnawati, N. (2014). Gambaran Pelaksanaan Pemasangan Infus Yang Tidak Sesuai Sop Terhadap Kejadian Flebitis Di Rsud Dr. Soediran Mangun Sumarso Kabupaten Wonogiri.

Kemenkes RI. (2017). Peraturan Menteri Kesehatan Republik Indonesia Nomor 40 Tahun 2017 Tentang Pengembangan Jenjang Karir Profesional Perawat Klinis.

Komisi Akreditasi Rumah Sakit. (2018). Standar Nasional Akreditasi Rumah Sakit. (P. Prof. Dr.H.Herry Garna,SpA(K), Ed.) (Edisi 1). Jakarta.

Mattox, E. (2017). Complications of Peripheral Venous Access Devices: Prevention, Detection, and Recovery Strategies. American Association of Critical-Care Nurses, 37(2). https://doi.org/10.4037/ccn2017657

Miller, S. L. (2016). Reducing IV Infiltrates in the Neonatal Population.

Odom, Brian, MS, PT, CWS; Lowe, Leah, PhD, DPT, PT, PCS; Yates, Charlotte, PhD, PT, P. (2018). Peripheral Infiltration and Extravasation Injury Methodology: A Retrospective Study.

Prakoso. (2016). Advance Vaskuler Acsess.

Riris, E., \& Kuntarti, K. (2014).

Pengetahuan Tentang Terapi

Intravena Berhubungan Dengan Perilaku Perawat Dalam Pencegahan 
NERS: Jurnal Keperawatan, Volume 15, No. 2, Oktober 2019, (Hal. 67-73)

Flebitis. Jurnal Keperawatan

Indonesia, 17(3), 108-118.

https://doi.org/10.7454/jki.v17i3.456

Riris, E., \& Kuntarti, K. (2017).

Pengetahuan Tentang Terapi

Intravena Berhubungan dengan

Perilaku Perawat dalam Pencegahan

Flebitis. Jurnal Keperawatan

Indonesia, 17(3), 108-118.

https://doi.org/10.7454/jki.v17i3.456 